等 性,

公 如圭 余

1 示名要

ス他芮軌

又十杽分二

リ八內 泌諸

興 分 臟 程

二 味 泌 器 藥

就厂贜夕物

厂儿器儿,

又事乐卵卵

早ナル巢巢

狀りモ血

腺。管

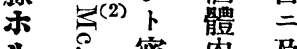

儿密览及

モ 復二ボ

ン

閶横尔關少影

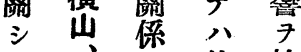

テ ${ }^{(5)}$ 艼 他 檢

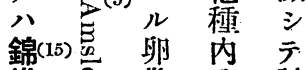

織巢分該

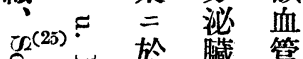

氙 於藏管

第第

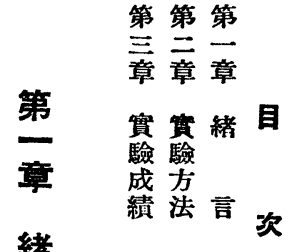

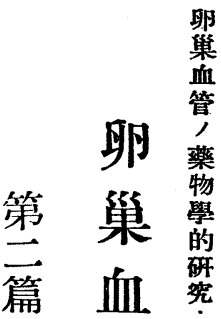

锗

血 諸

管

第 第

管 種 ノ野

二內

主五四

要章章

言䕦結總

及分燕

ボ必

ス臟物

論趈

作器 學

學 京

年的

䜿帝國眆研

卵

.士 學

毒( 他 助 性

醫

巢 究

內 學

等 分 或 7

ヒ染摸 求

等 $\boldsymbol{~}$ 臟 抗

鼻器的”。

丸 当出作

本老用

$\boldsymbol{\mu}=2 \pi$

モ 就 二 ル

テ 就 八

八亭( ${ }^{(8)}$ 如

ర2(17)柿 ${ }^{(9)}$ 何 俟

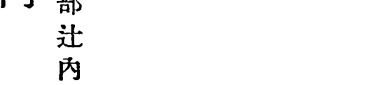

野科

室㝘

幸

作

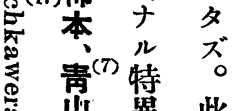

山 異此 
綿 上 隇 織

栓 菌及内前

ヨ $\exists$ 生 ビ 分篇

施 ク 理脂 泌 同

卵 三 乳的肪 藏 樣

巢厅 錰食組 器 新

血 水 7 馧 織 食 鮮

管 室 洗 水

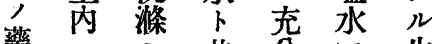

藥 = 物 共 分工牛

學三人三除手沺

的古之猺去

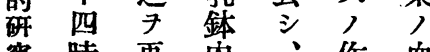

宪時再丙作 血

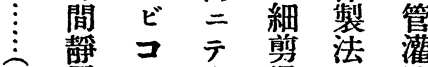

丙置儿踠混公流

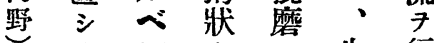

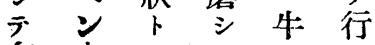

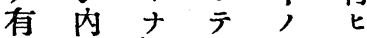

侪三范新多

成移、獎鮮》。

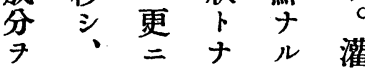

抽力蔁 辛甲流

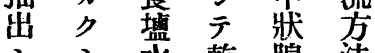

言永翰腺法

之原燥

$\exists$ 生注立脂前

遠理加 穴腺篇

心的文更的

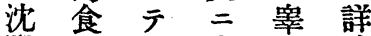

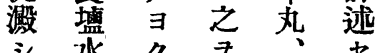

水》皮菠

厂, 摆粉 卯

虚㝨挷染 7

澄 量 $三$ 留品

$\exists$ 开

探五コ。定省

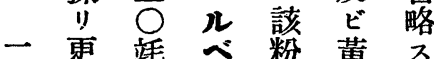

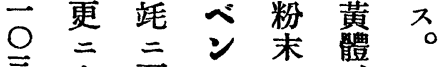

三之至三人

子移五副

濾シ シ瓦督

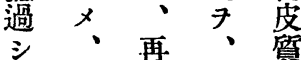

テコビ初 7

得几食只用

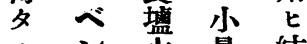

液气永量結

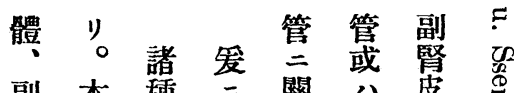

副本種三關公落

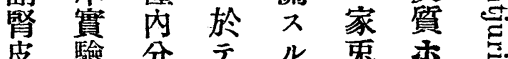

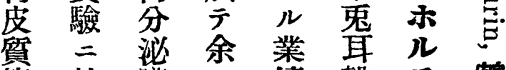

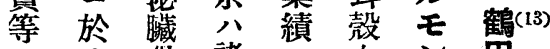

厂签諸具思

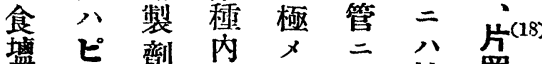

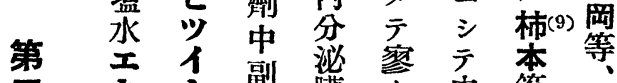

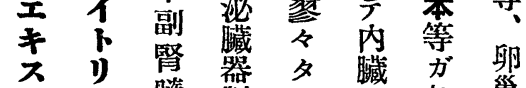

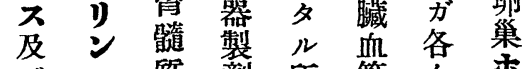

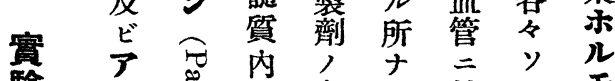

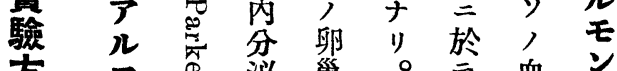

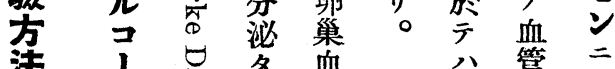

法 10 具分管

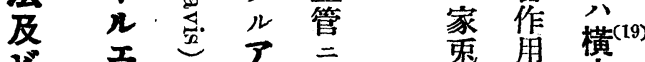

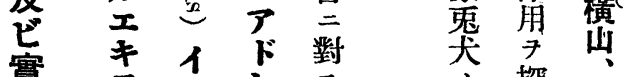

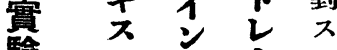

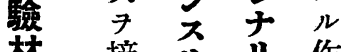

林 摘 可 作

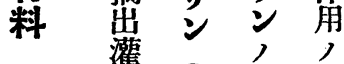

流白卵檢

生帛巢采

卵突 血 7

集 管企

血及 $=\bar{F}$

管 ビ 對 多

二告 $ᄌ$

㤰晶莋

七腺角

券脑就

名腺少

。殬既

杂煎

卵篇

巢

間 於

赛敛

飞゙ 迹

黃
探

堅求层(20)

脾

旰咅

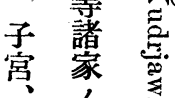

心檢兽

稂笔

更

肺公兽

䐟 末

等梢、粱

血管

於

离䇪总

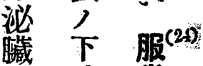

器 肢

血 血
禁兵 


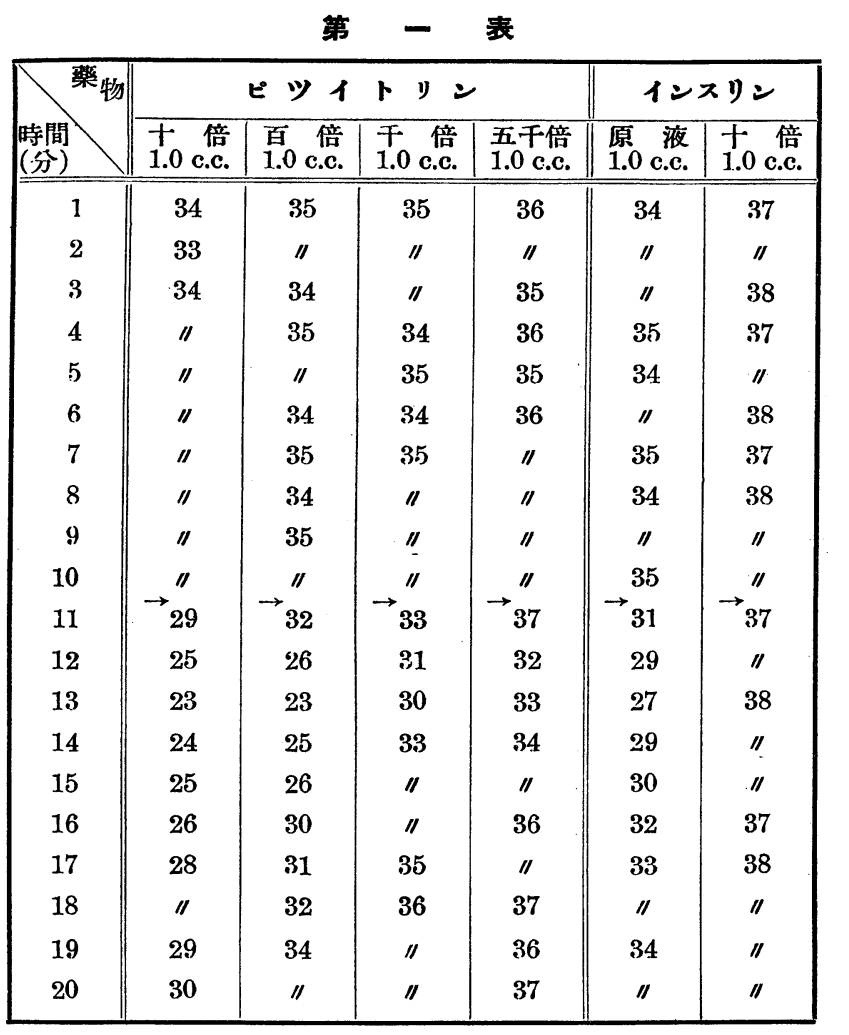

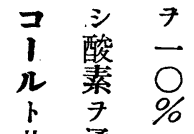

共通) 卵

二ズ I 巢

乳事管

錸事 ス 管

二時 菜

亏 間 。 學

泥更唯的

狀 二 副研

二之腎 究

混采皮

磨一質

シ $\bigcirc$ 䆬

更分永题

文 規 混

几定 入

光

ル塯 ル

尹 ド

注 上 ᄂ

入テ广

シ 中

テ 和 ソ

攪七

㨔り。破

、ア塯

昇體七至タ水テ四コ水ン

七第古 シ キ

儿葉ク一第 心

事 $\varrho^{(1)}$ ぴ 章 勿二荍竓

ガ 認 ス

ラ 靜

ラ 靜

、内 总

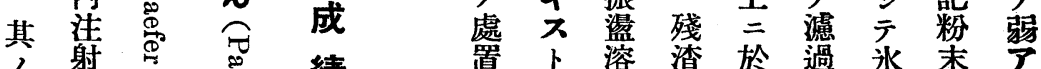

, 射 綪 置 $上$ 溶渣於過水末尔

他 $=$ 离 靕

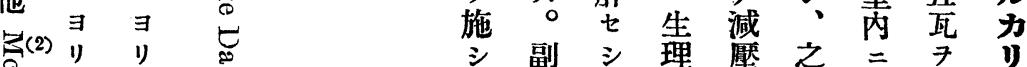

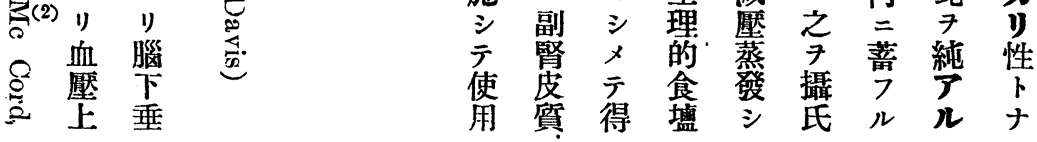




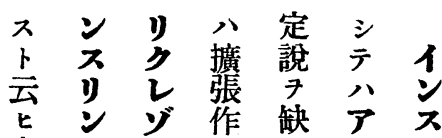

卵青二小角ク、゙リ

巢山於ル斗レン

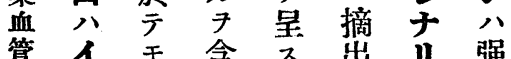

亚ン收有ル 血ソ 勄

物 ス 縮 ス モ管 ガナ

學りスル、

的 $ン$ 蛙關榜降

研合述 以婜 シ 二 血

究节 今゙ 贜 テ 血 糖

：号夕稀 血八壓作

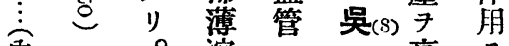

内 $\bigcirc$ 溶二公高

野 ○杮(9)葆八幕山有

云本少 無具作ビニ シ

八家管 用蛙反

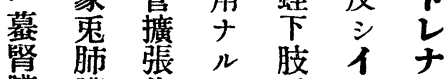

臟 獩 作 $キ$ ・

動 血用報内不

胍管 心售臟りト

及二イリ

ビ於ン。家八拮

腎テ 万更兔或拀

門 1リ年八ス

静ンン 吳(B) 殸血ル

脈 不冏心壓事

二リ有 1 ビタ 實

對ンナソ 內 降分

初已リリ 百獩下諸

メ 衫論 ン、管 シ

血 过 渝等

管 $\bigcirc$ 家宣 於 ル シ

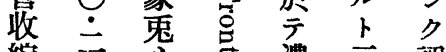

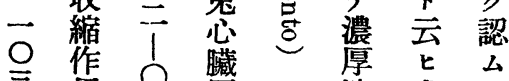

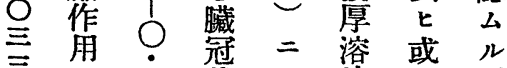

7 五狀

有竓動血公影ナ

ス八脈管 收響

ル收收縮龺モ

モ縮 $i$ 縮 7 シ 血

次作分劑稀点管

腎 薄 ル 溶去 三

贜ナ柋ト荍テ對

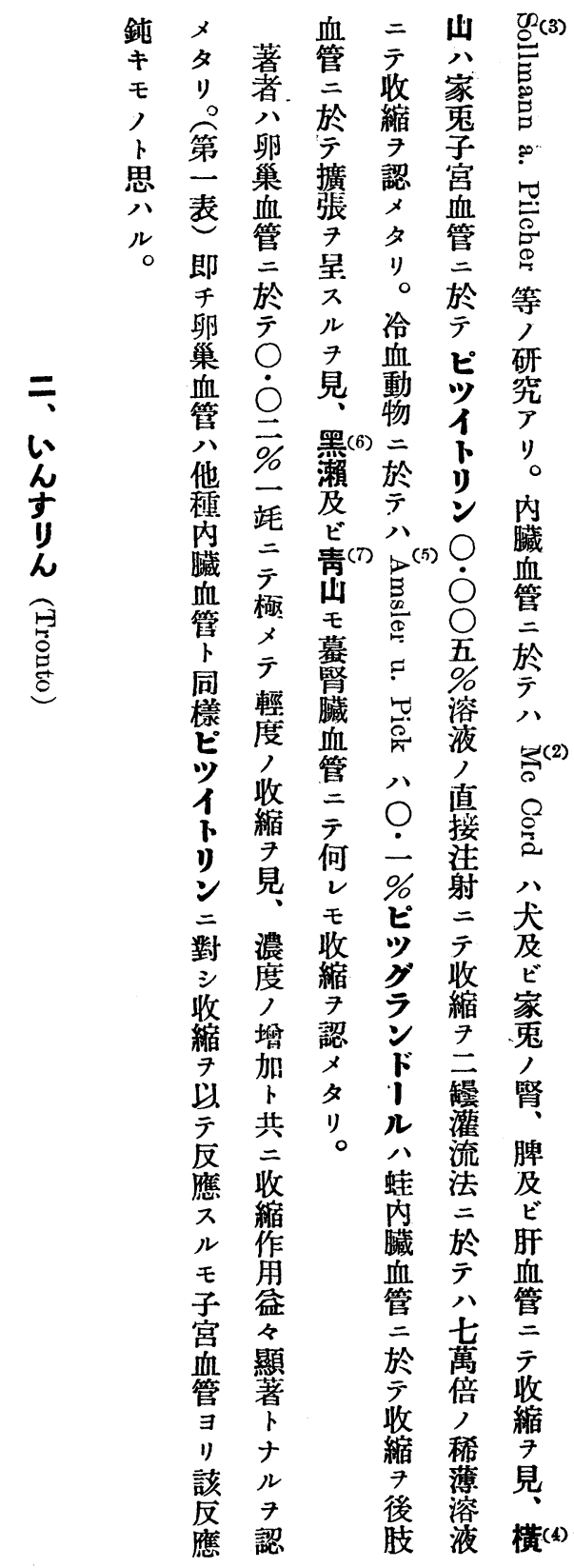

第卵 亏 7 子

思二巢擴 認宮的

ハ 表 血 張 メ 血

于 於不於等

卵 $ル$ 冷 テ,

巢 $\bigcirc$ 血 ピ 研

血管 ○ 見 動

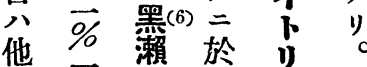

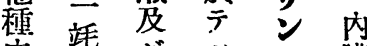

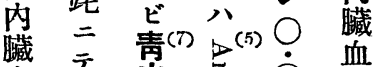

血 粫 出

同テ幕た五 於

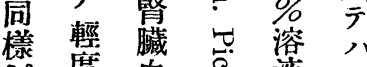

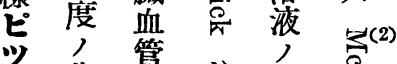

1 收

》 手何 $\overrightarrow{0}$ 注

= モ ピ 犬

シ度 縮 グ 收 ビ

收ノ丹 ラ 縮 家

縮 增 認ソタ 兔

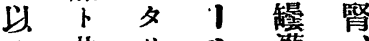

反 共 リ

應 收 蛙 法及

ス 緶 品 藏 於 訮

モ用 血 テ 血

子 管 分

血顯萬 テ

管 著 亏 倍 收

$\exists$ 卜收, 縮

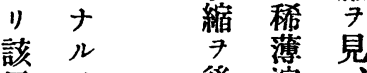

應認 䏡容 横(4) 
第 二 表

\begin{tabular}{|c|c|c|c|c|c|c|c|c|}
\hline 藥 & \multicolumn{4}{|c|}{ 甲爿腺食㙳水エキス } & \multicolumn{4}{|c|}{ 同 アルコリルエキス } \\
\hline $\begin{array}{l}\text { 時間 } \\
\text { (分) }\end{array}$ & $\begin{array}{l}\text { 十 倍 } \\
1.0 \text { c.c. }\end{array}$ & $\begin{array}{l}\text { 百 倍 } \\
1.0 \text { c.c. }\end{array}$ & $\begin{array}{l}\text { 五百倍 } \\
1.0 \text { c.c. }\end{array}$ & $\begin{array}{l}\text { 千 倍 } \\
1.0 \text { c.c. }\end{array}$ & $\begin{array}{l}\text { 十 倍 } \\
1.0 \text { c.c. }\end{array}$ & $\begin{array}{l}\text { 百 } \text { 倍 } \\
1.0 \text { c.c. }\end{array}$ & $\begin{array}{l}\text { 五百倍 } \\
1.0 \text { c.c. }\end{array}$ & $\begin{array}{l}\text { 千 倍 } \\
1.0 \text { c.c. }\end{array}$ \\
\hline 1 & 37 & 39 & 37 & 40 & 36 & 31 & 32 & 30 \\
\hline 2 & "I & $" 1$ & "I & /I & "I & 30 & "I & "I \\
\hline 3 & 36 & 40 & "I & "I & $\|$ & "I & "I & 31 \\
\hline 4 & 37 & 39 & 36 & "I & "I & 31 & 33 & "I \\
\hline 5 & "I & "I & 37 & 41 & "I & "I & 32 & 30 \\
\hline 6 & 30 & 30 & 36 & 40 & "I & "I & 30 & 31 \\
\hline 7 & 25 & 27 & 37 & "I & 37 & 30 & 31 & "I \\
\hline 8 & 18 & 26 & "I & 41 & 36 & II & 35 & 30 \\
\hline 9 & 16 & "I & "I & 40 & "I & 31 & 46 & "I \\
\hline 10 & 17 & 27 & 36 & "I & "I & "I & 52 & "I \\
\hline 11 & 21 & 29 & 29 & 39 & 33 & 27 & 56 & 31 \\
\hline 12 & 25 & 31 & 27 & 35 & 26 & 23 & 58 & 33 \\
\hline 13 & 28 & "I & 28 & 40 & 23 & 17 & 59 & "I \\
\hline 14 & 29 & 32 & 31 & 44 & 21 & "I & 55 & 34 \\
\hline 15 & 31 & "I & 33 & 45 & 20 & 18 & 46 & 36 \\
\hline 16 & 32 & 34 & 34 & 44 & 21 & 19 & 39 & 35 \\
\hline 17 & 33 & 33 & "I & 45 & "I & "I & 35 & 34 \\
\hline 18 & "I & 34 & 36 & 46 & 23 & 21 & 32 & "I \\
\hline 19 & 34 & "I & 37 & 45 & 25 & 22 & 30 & "I \\
\hline 20 & "I & 35 & 38 & "I & 26 & "I & "I & 33 \\
\hline
\end{tabular}

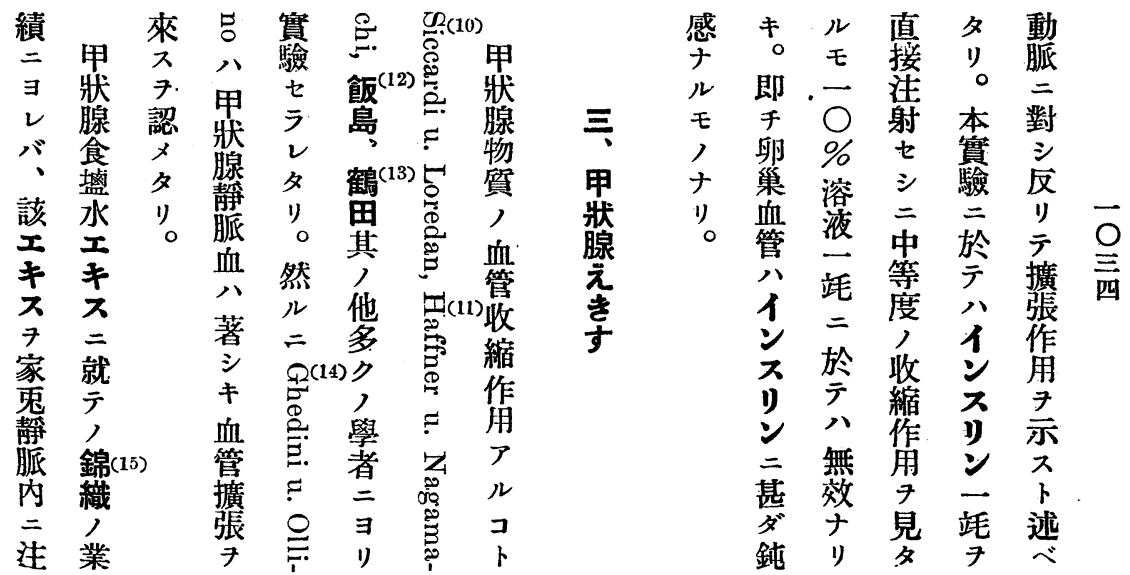



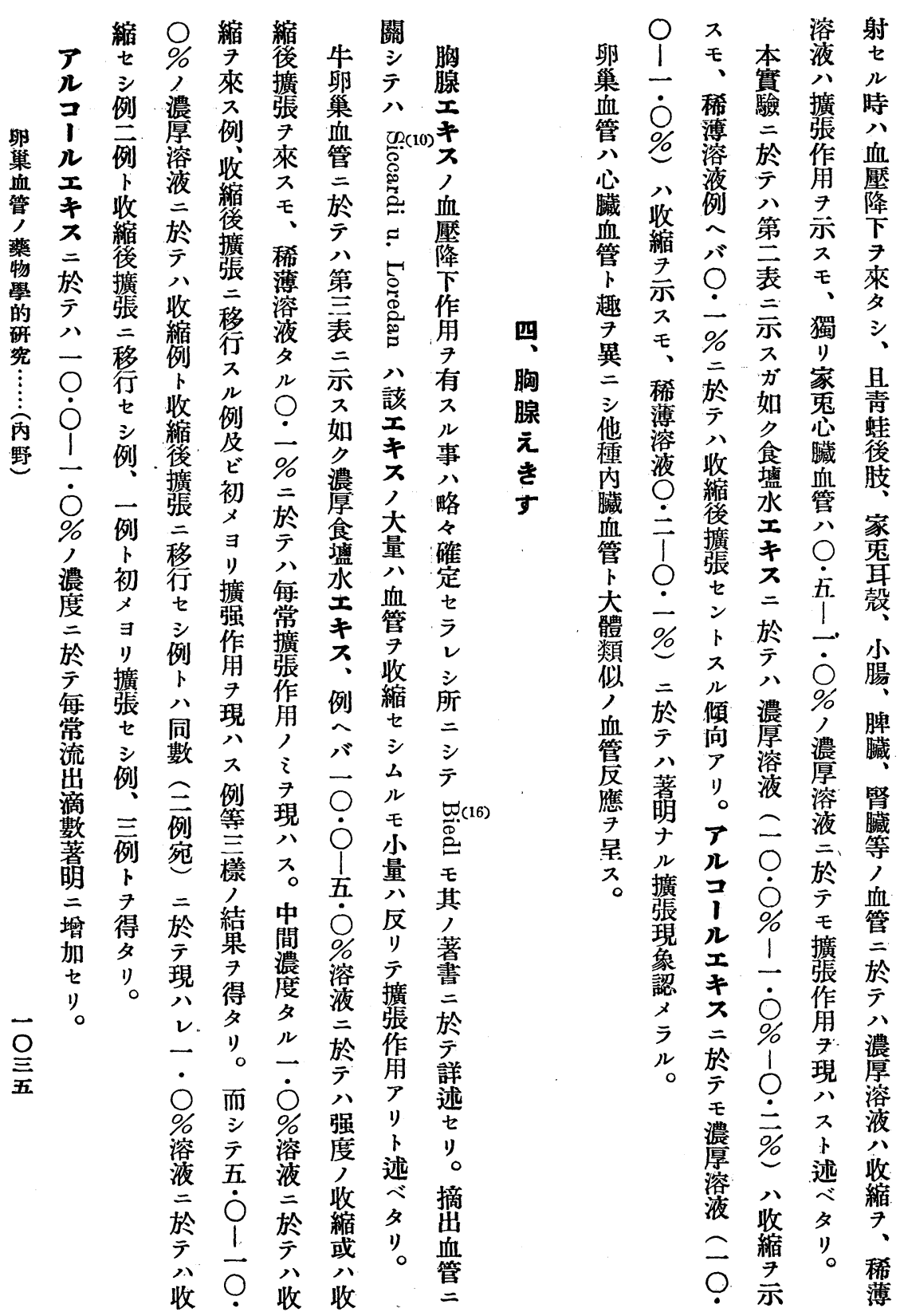
第 三 表

\begin{tabular}{|c|c|c|c|c|c|c|c|c|c|}
\hline 牙 & \multicolumn{6}{|c|}{ 胸腺食㙳水エキス } & \multicolumn{3}{|c|}{ 同アルコールエキス } \\
\hline $\begin{array}{l}\text { 時間 } \\
\text { (分) }\end{array}$ & $\begin{array}{l}\dagger \text { 倍 } \\
1.0 \text { c.c. }\end{array}$ & $\begin{array}{l}\text { 十 倍 } \\
1.0 \text { c.c. }\end{array}$ & $\begin{array}{l}\text { 百 倍 } \\
1.0 \text { c.c. }\end{array}$ & $\begin{array}{l}\text { 百 倍 } \\
1.0 \text { c.c. }\end{array}$ & $\begin{array}{l}\text { 百 倍 } \\
1.0 \text { c.c. }\end{array}$ & $\mid \begin{array}{ccc}千 & \text { 倍 } \\
1.0 & \text { c.c. }\end{array}$ & \begin{tabular}{|l} 
干 \\
1.0 \\
c.c.
\end{tabular} & $\begin{array}{l}\text { 百 倍 } \\
1.0 \text { c.c. }\end{array}$ & 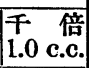 \\
\hline 1 & 41 & 33 & 45 & 39 & 35 & 34 & 35 & 37 & 34 \\
\hline 2 & "I & " & 44 & 40 & $\|$ & $\|$ & / & $\|$ & $\|$ \\
\hline 3 & 42 & "I & / & 39 & " & 35 & $\|$ & $\|$ & "I \\
\hline 4 & 41 & II & 45 & 40 & "I & 34 & II & II & 33 \\
\hline 5 & 42 & 32 & II & 39 & 36 & II & II & II & 34 \\
\hline 6 & "I & 24 & 44 & 40 & 85 & II & "I & "I & 33 \\
\hline 7 & 41 & 17 & "I & "I & 36 & "I & 34 & II & 34 \\
\hline 8 & 42 & 18 & "I & "I & II & "I & 35 & II & 33 \\
\hline 9 & "I & 28 & II & "I & 35 & "I & 34 & "I & II \\
\hline 10 & " & 43 & "I & $\|$ & 36 & "I & 35 & II & II \\
\hline 11 & 29 & 47 & 43 & 30 & 36 & 35 & 40 & 38 & 36 \\
\hline 12 & 20 & 46 & 38 & 35 & 38 & 38 & 47 & 40 & 38 \\
\hline 13 & 22 & 45 & 30 & 38 & 40 & 40 & 51 & 46 & 39 \\
\hline 14 & 38 & "I & 28 & 40 & 44 & 42 & 46 & 47 & 37 \\
\hline 15 & 40 & 43 & 35 & 42 & 46 & 40 & 41 & 43 & 34 \\
\hline 16 & 42 & 41 & 41 & 45 & 47 & 37 & 40 & 42 & 35 \\
\hline 17 & $\|$ & 38 & 42 & 46 & " & "I & " & "I & 34 \\
\hline 18 & 40 & 31 & 43 & 43 & 45 & 36 & 41 & 41 & " \\
\hline 19 & 41 & 30 & 45 & 42 & 38 & "I & 38 & 40 & 33 \\
\hline 20 & 42 & "I & 46 & "I & 35 & "I & "I & $\|$ & 34 \\
\hline
\end{tabular}

スルベ二張作タ拿縮占於於丸

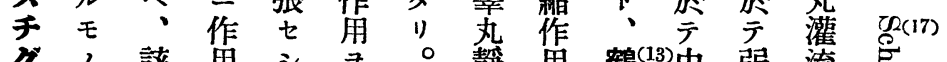

今。 該 潗

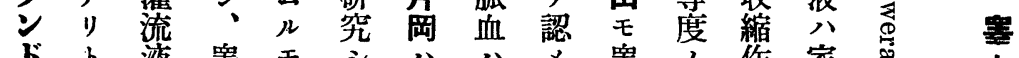

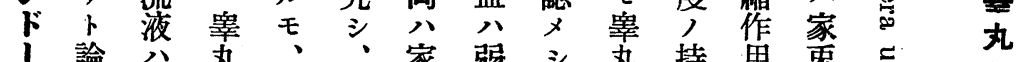

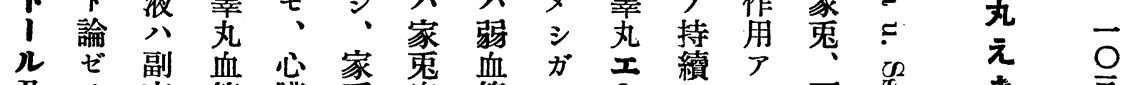

及

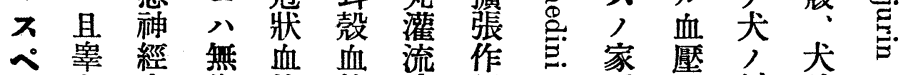

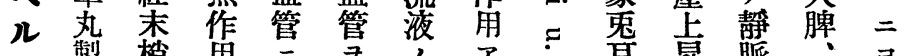

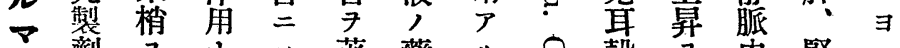

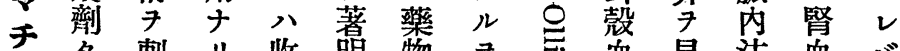

ンタ 刺り收奛物

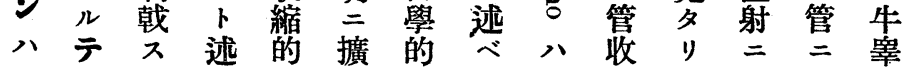




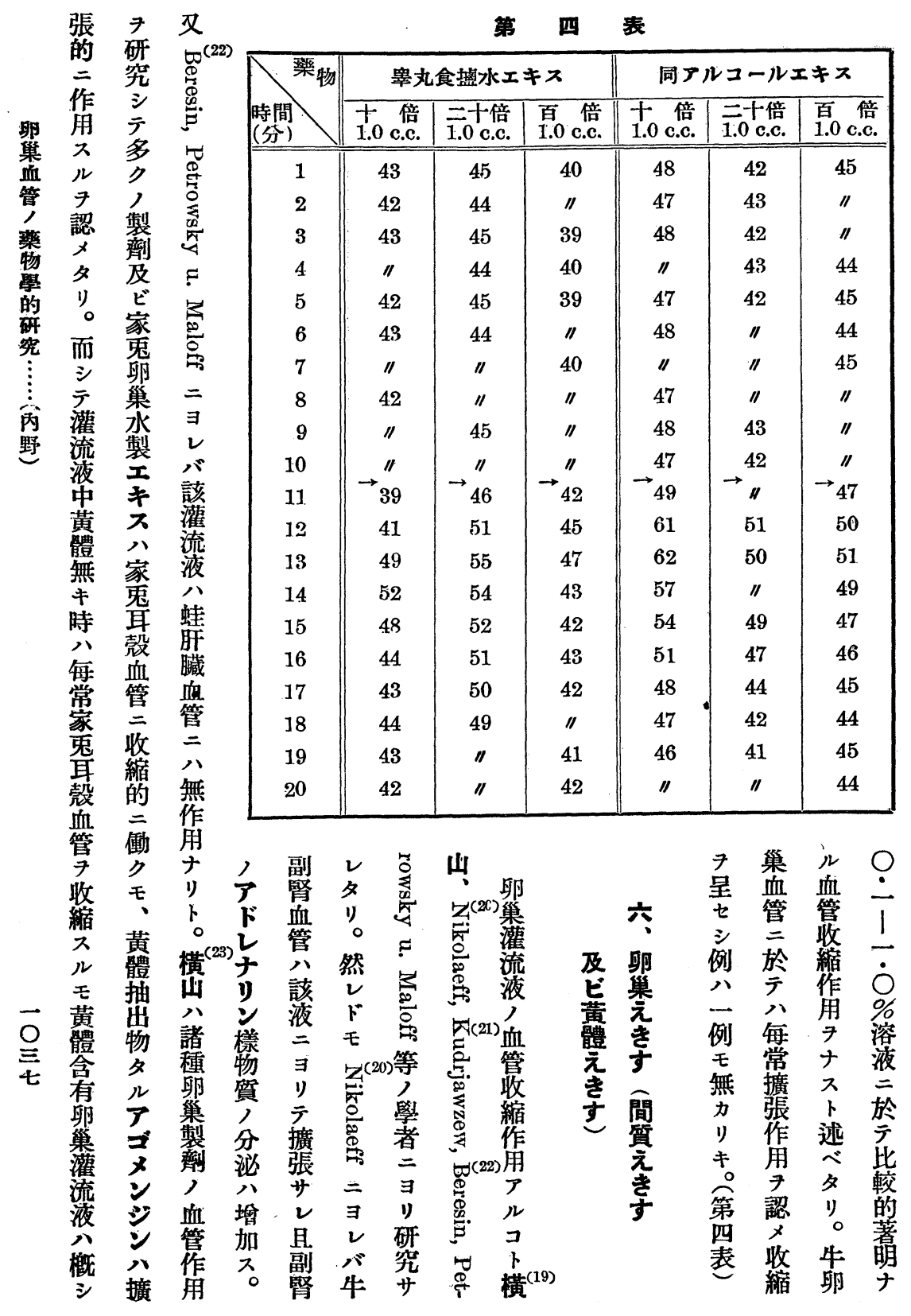


第五表

\begin{tabular}{|c|c|c|c|c|c|c|c|c|}
\hline 藥物 & \multicolumn{4}{|c|}{ 卵巢間質食壚水エキス } & \multicolumn{3}{|c|}{ 同アルコールエキス } & 濾胞液 \\
\hline $\begin{array}{l}\text { 時間 } \\
\text { (分) }\end{array}$ & $\begin{array}{l}\text { 十 倍 } \\
1.0 \text { c.c. } \\
\end{array}$ & $\begin{array}{l}\text { 百 倍 } \\
1.0 \text { c.c. }\end{array}$ & $\begin{array}{c}\text { 千 倍 } \\
1.0 \text { c.c. } \\
\end{array}$ & \begin{tabular}{|cc} 
千 倍 \\
1.0 c.c. \\
\end{tabular} & $\begin{array}{l}\text { 倍 } \\
1.0 \text { c.c. } \\
\end{array}$ & $\begin{array}{l}\text { 二十倍 } \\
1.0 \text { c.c. } \\
\end{array}$ & $\begin{array}{l}\text { 百 } \text { 倍 } \\
1.0 \text { c.c. } \\
\end{array}$ & $\begin{array}{l}\text { 原 液 } \\
1.0 \text { c.c. } \\
\end{array}$ \\
\hline 1 & 45 & 43 & 40 & 42 & 41 & 41 & 41 & 43 \\
\hline 2 & / & " & $\|$ & "I & 40 & 40 & 40 & $" \prime$ \\
\hline 3 & " & 42 & $" 1$ & $" \prime$ & 41 & 41 & 41 & 42 \\
\hline 4 & 44 & 43 & 41 & " & 40 & " & " & 43 \\
\hline 5 & 45 & " & " & " & " & $" \prime$ & $4: 0$ & " \\
\hline 6 & 32 & " & 40 & $" 1$ & " & " & 41 & 42 \\
\hline 7 & 17 & " & 41 & $\|$ & " & 40 & 40 & 43 \\
\hline 8 & 12 & 42 & 40 & " & " & 41 & 41 & " \\
\hline 9 & 13 & 43 & "I & $" \prime$ & "I & "I & 42 & "I \\
\hline 10 & "I & " & 41 & " & "I & 40 & 41 & "I \\
\hline 11 & "I & $\rightarrow_{39}$ & $\rightarrow_{39}$ & $\rightarrow_{35}$ & $\overrightarrow{4} 47$ & $\rightarrow_{41}$ & $\rightarrow_{40}$ & $\rightarrow 38$ \\
\hline 12 & 14 & 26 & 30 & 34 & 58 & "I & 42 & 35 \\
\hline 13 & 15 & 28 & 27 & 41 & 49 & 43 & 44 & 37 \\
\hline 14 & 20 & 33 & 33 & 42 & 42 & 44 & "I & 38 \\
\hline 15 & 24 & 36 & 38 & 47 & "I & 47 & 46 & 36 \\
\hline 16 & 27 & 39 & 39 & 44 & 41 & 45 & 45 & "I \\
\hline 17 & 31 & 40 & 41 & 42 & 42 & 43 & 44 & 37 \\
\hline 18 & 33 & "I & "I & "I & 43 & II & 43 & 39 \\
\hline 19 & 34 & 42 & 42 & "I & 42 & 42 & 40 & 42 \\
\hline 20 & 35 & "I & " & 11 & "I & 41 & 41 & 43 \\
\hline
\end{tabular}
第
表兩卵 。綃

ビキ巢角巢

共共體 ル胞

表收工モ液

縮 キ 該 少

作 万液 卵

用八, 巢

食十血

垍 倍 管

7 水㴦

呈液 對

七ア 心

リル 無 輕

第

五几十ナ收
ル 云傾 $\overrightarrow{\%}$ 收牛縮 家 今゙ テ 7 縮 卵 シ 耳縮 八現於作巢么殼力゙作 濃心テ用血ル血反用 稀 ス 八

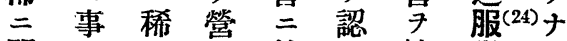
關 $\boldsymbol{\gamma}$ 公於

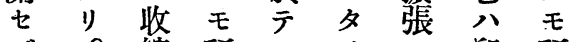
ズっ縮稀八リ方卵稀 每乃後薄間。黃巢 常儿擴溶質體 濾擴 擴 コ張掖 食采胞張

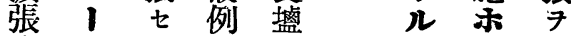
作几ン八水 モル示 用エトバエ $エ コ 一$ ス

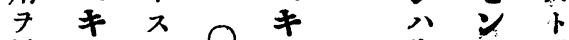
見スル? 收小述 


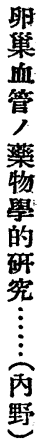

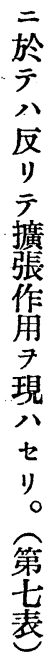

\begin{tabular}{|c|c|c|c|c|c|c|}
\hline$>$ & 卵巢直 & 體食壚小 & エキス & 同 $>$ & コール & :キス \\
\hline $\begin{array}{l}\text { 時間 } \\
(\text { (分) }\end{array}$ & $\begin{array}{l}\text { 三十倍 } \\
1.0 \text { c.c. }\end{array}$ & $\begin{array}{l}\text { 百 倍 } \\
1.0 \text { c.c. }\end{array}$ & $\begin{array}{l}\text { 千 倍 } \\
1.0 \text { c.c. }\end{array}$ & $\begin{array}{l}\text { 三十倍 } \\
1.0 \text { c.c. }\end{array}$ & $\begin{array}{l}\text { 百 倍 } \\
1.0 \text { c.c. }\end{array}$ & $\begin{array}{l}\text { 千 倍 } \\
1.0 \text { c.c. }\end{array}$ \\
\hline 1 & 36 & 34 & 31 & 37 & 41 & 39 \\
\hline 2 & " & "I & "I & "I & "I & "I \\
\hline 3 & 35 & "I & 30 & 38 & "I & "I \\
\hline 4 & 36 & "I & 31 & 37 & "I & "I \\
\hline 5 & 35 & 35 & 30 & 38 & "I & 40 \\
\hline 6 & "I & 34 & "I & 37 & 42 & 39 \\
\hline 7 & 36 & 35 & 31 & 38 & 41 & "I \\
\hline 8 & "I & 34 & 30 & "I & II & 40 \\
\hline 9 & 35 & 35 & "I & "I & "I & 39 \\
\hline 10 & "I & "I & "I & II & "I & "I \\
\hline 11 & 34 & 31 & 29 & 23 & 28 & 36 \\
\hline 12 & 27 & 29 & 26 & 15 & 26 & 34 \\
\hline 13 & 23 & 27 & 25 & "I & 30 & 35 \\
\hline 14 & "I & 26 & 26 & 20 & 33 & II \\
\hline 15 & 24 & 28 & 28 & 23 & 35 & 36 \\
\hline 16 & 25 & 31 & 29 & 25 & 37 & "I \\
\hline 17 & 26 & 33 & "I & 28 & 38 & "I \\
\hline 18 & "I & 84 & 30 & "I & II & 37 \\
\hline 19 & 27 & 35 & " & "I & "I & 38 \\
\hline 20 & "I & "I & 31 & 29 & "I & ." \\
\hline
\end{tabular}

收 縮 出 花 \% 度 牛 血 柿 $^{(9)}$ 質

莋

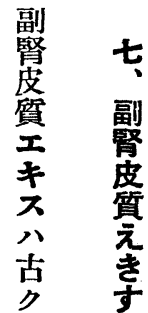

$\underset{\mathrm{O}}{\stackrel{\mathrm{O}}{\mathrm{H}}}$

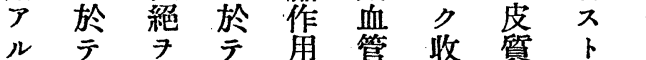

モ心見八ア三縮ノ云

稀濃ル作り於七食少

薄厚 コ 角

溶溶

例 ニリテ濃盐述キ出ヨ

人テ。强厚水会

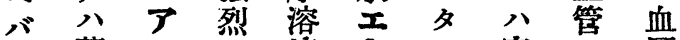

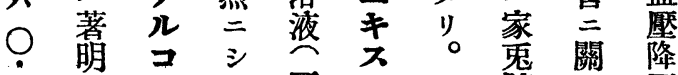

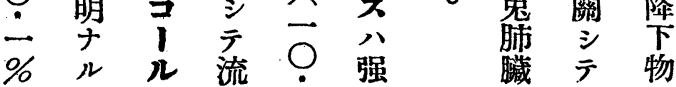




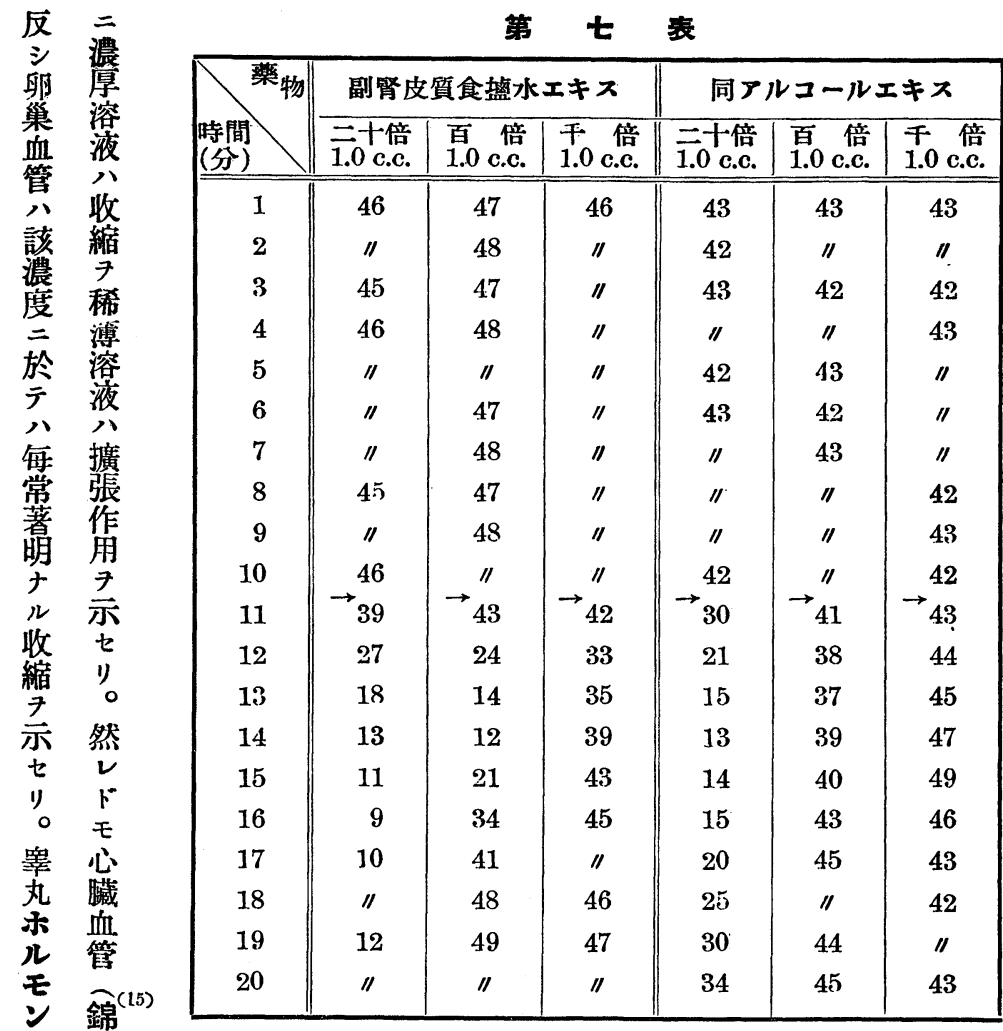

二織

關血キ服作劣ル考, 丸

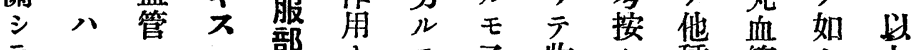
テ $\vec{a}$ 部ナ モ子收七 種 管キ 上

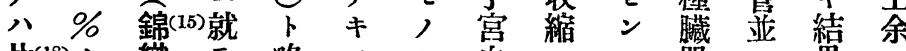
片(18)) 織厅略八、血 入二器三人果, 四

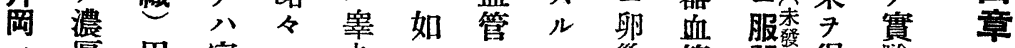

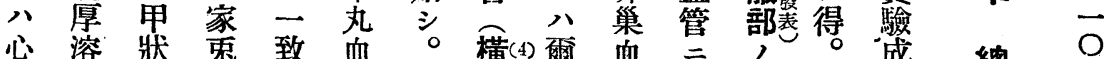

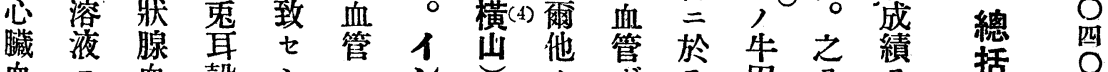

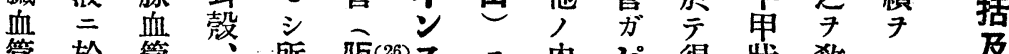

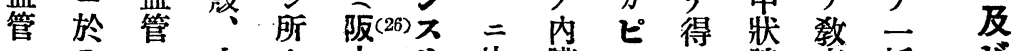

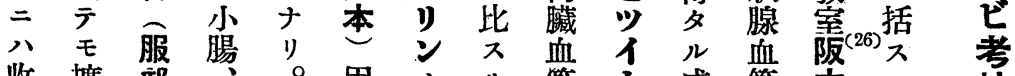
縮 㖘 部 脾 甲 狀 殆 的 スト、狀腺ド著同ソ 作二同婜 腺 血血管 榜 
第八表

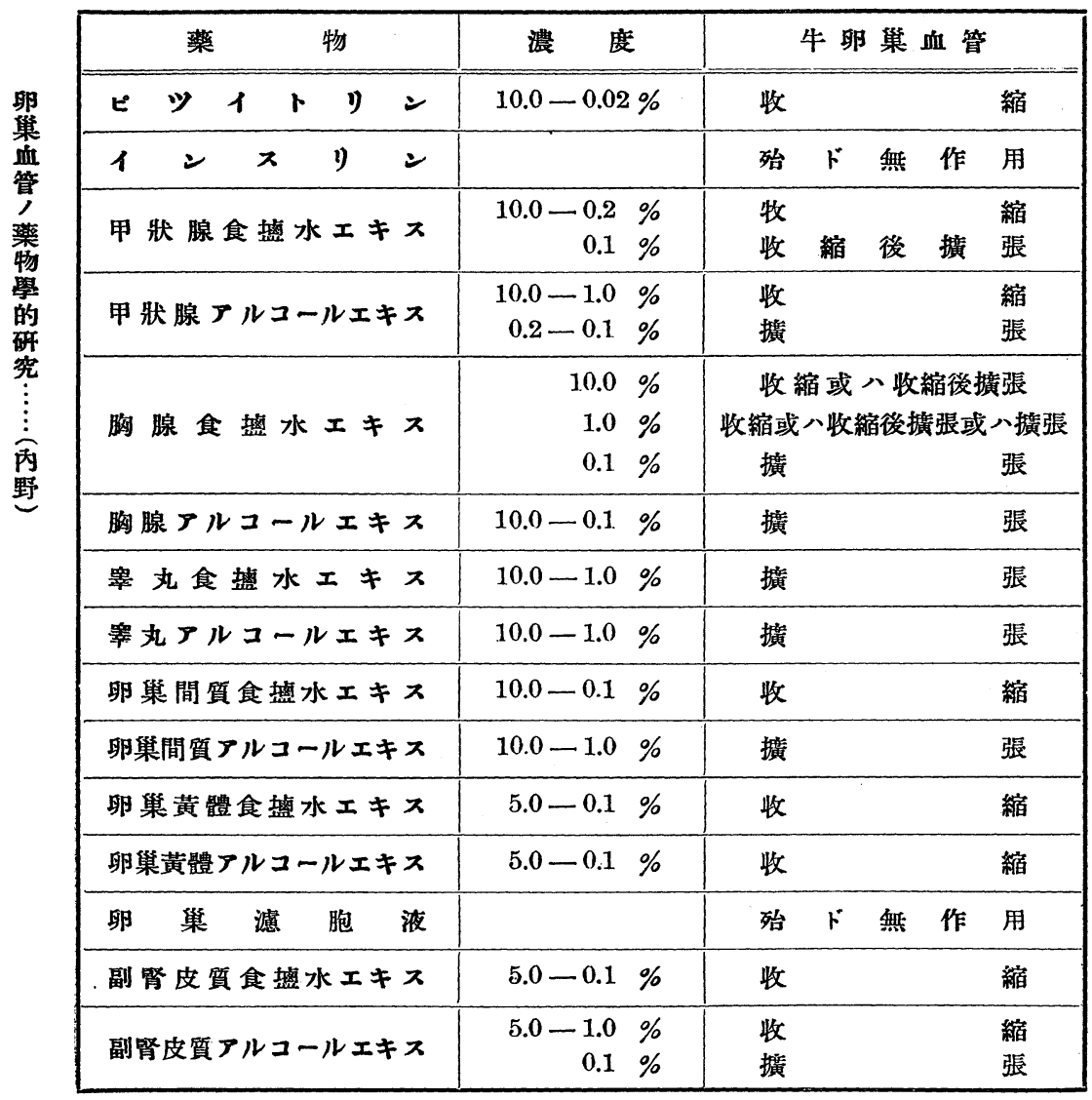

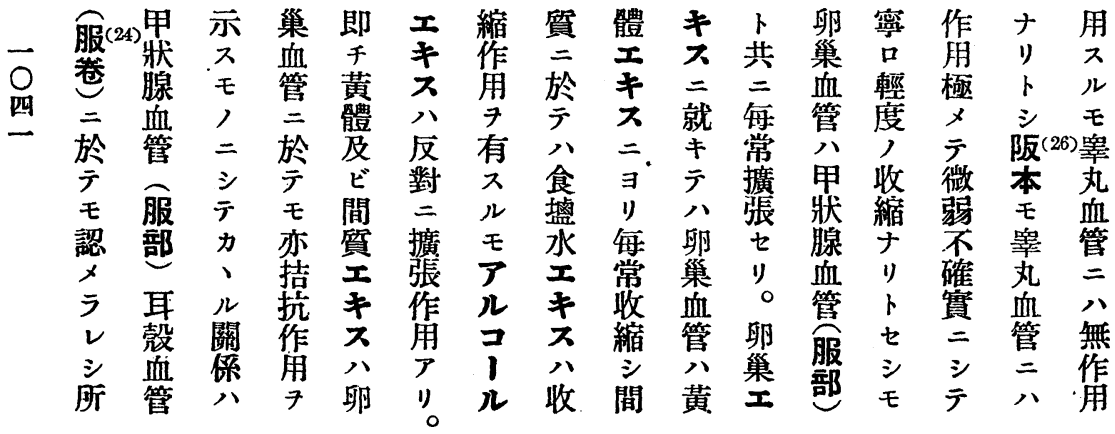


四三 三 : 少 余

卵胸甲ピエ

巢腺狀 $ツ キ ヒ ゚$

間皮腺不 ス

質ビ, ト キイ

食拿食 $\boldsymbol{V}$ 製

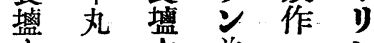

水, 沓並流

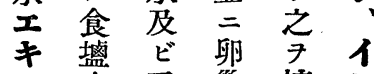

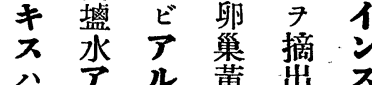

卵年體灌

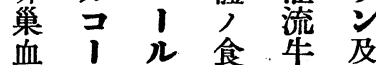

管 ルエ壒 卵 ビ

爾 $\neq$ 水巢牛

收 工不二甲

維 キ 炛作 狀

シ 公浱 同用腺

厶 共溶儿シ 胸

ル 㴕コ又腺

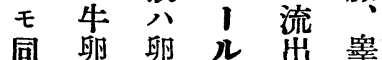

品巢、滴杂

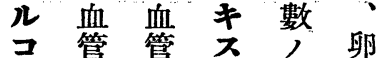

17 八增巢

几擴 收牛減間

工張縮 䀠 7 質

キ 七 $七$ 巢 觀

ス シ シ 血 祭. 同

公 $x$ 管 竞

擴。稀子次體

張港收, 及

七 溶 縮 如 ビ

シ 液七副

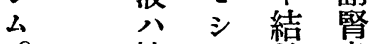

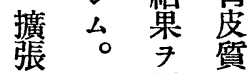

七 得 $\exists$

シ 多

台肾。食

食

水

ビ
略牀暴於 テ溶りナ

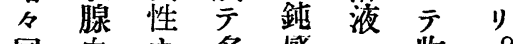

同血于多感二收。

樣 管 り少ナ 於 緶 胸

等卜其り

反卜斷, ○八認工巢

應, ズ趣斯輕 メキ 血 子間ルチ度タス管 呈二二異人如少二蒜 分公二如擴。於樂 第一著 聊 ス キ 躊 所巢示皮甲研

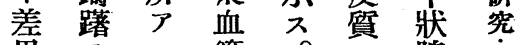
異 $タ$ 管。王腺

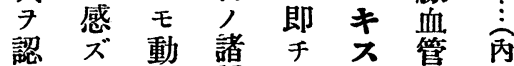
$x$ 物種 甲二 難 モ 種 内 狀 對 服

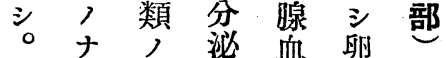
要り 相虔管巢卜

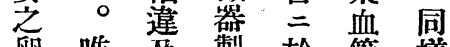
卵 唯 製 於 管 樣 巢 睪 ビ 劑 ケ公二 血丸其二 稍擴 管 血了對 成 年 管 他 入 績 鋔 作 諸及人ル敏用 種 ビ 諸 反類二尹 内冠條應似收認 分牀件 $尹$ 縮么 泌血 7 他 $○ ル$ 物 管 顧 種 反 上.

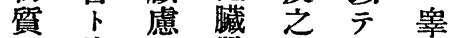
二比七器墨 反 丸 對較 ル血丸應血 シ ス 時 管 血 $九$ 管

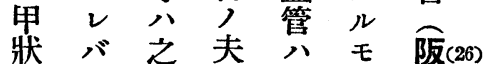

腺稍学年副向本 $\overrightarrow{0}$ 血 其管筫 其了直範留コ稀三 了趣于ス方䔔 他 7 ニ キ ル溶 諸異 卵二ス工液 藏三巢個二キ= 器 入 血 多對 ス 於 血 ル 管 つ シ ハテ 管 モ 


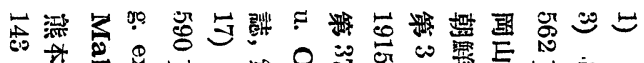

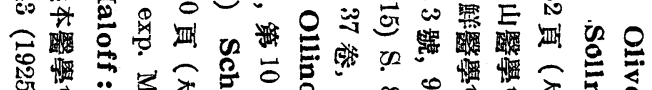

卵

巢

In

管

妾

薬

學

的

磁

究

埇

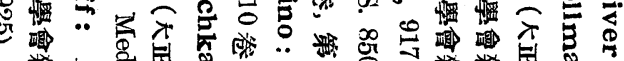

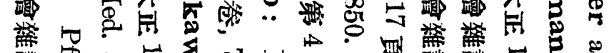

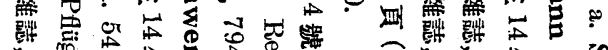

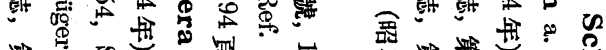

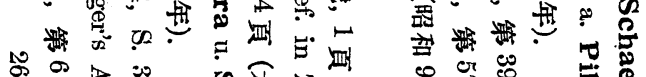

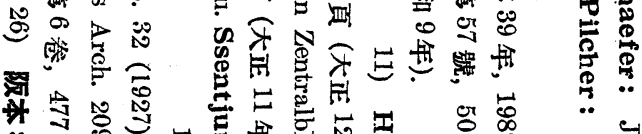
月.

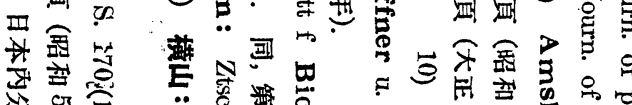

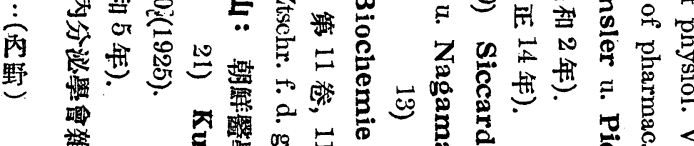

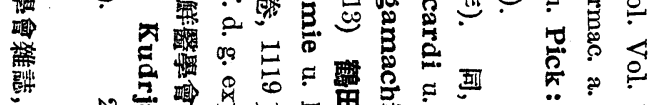

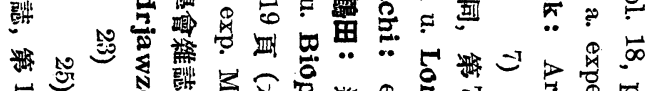

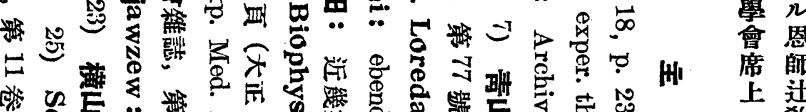

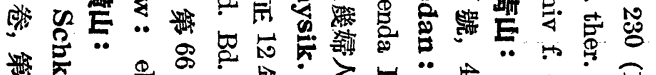

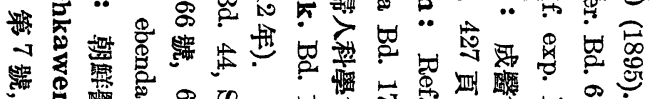

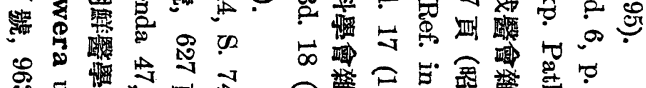
品 顷

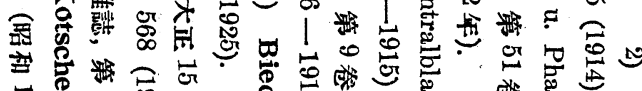

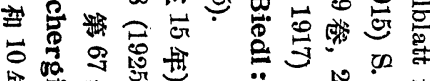

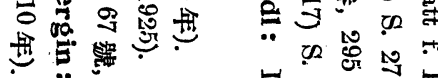

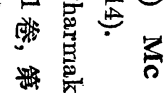

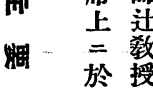
4. $\overline{\text { 並 }}$ 㱰菊 表 菊 》。前 公張

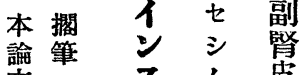
交嫦页台皮 一者食 公楾”殆搵

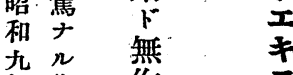
年御作至

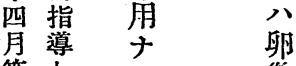
第御少巢 回校夏 本 $尹$ 疋 永賜箯 泌 夕 七 事恩思

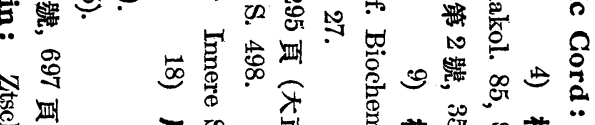

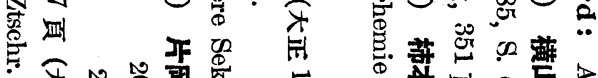

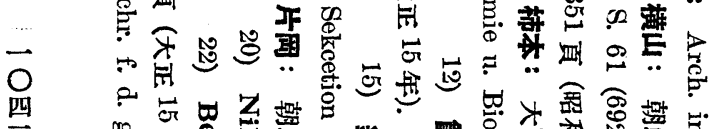

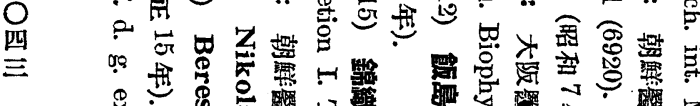

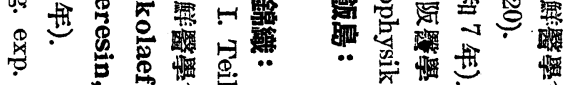

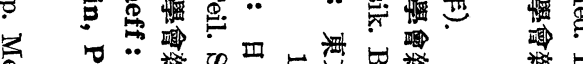

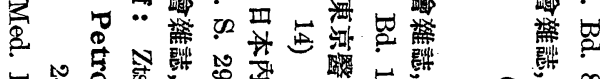

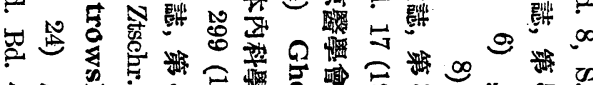

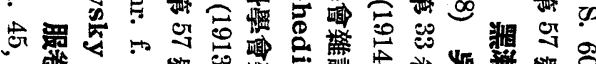

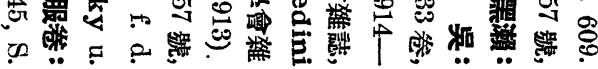




\title{
Über die Wirkungen der Extrakte verschiedener Blutdrüsen des Rindes auf die Gefässe von isolierten Rinderovarien.
}

\author{
Von \\ Dr, K. Uchino.
}

(Aus der I. Med. Klink der Kaiserl. Universität zu Kyoto in Japan. Direktor : Prof, Dr. K. Tsuji.)

Der Verfasser studierte die Wirķungen einiger Hormonpräparate (Pituitrin und Insulin) und der Extrakte verschiedener Blutdrüsen des Rindes (Schilddrüse, Thymus, Nebennierenrinde, Hoden, Ovarialinterstitium mit Follikel und Corpus luteum) auf die isolierten durchströmten Ovarialgefässe des Rindes.

Die Resultate waren wie folgt:

1) Physiologische Kochsalizlösungs- und Alkoholextrakte des Corpus luteum verengerten die Ovarialgefaesse des Rindes.

2) Der Kochsalzlösungsextrakt des Ovarialinterstitiums verengerte die Ovarialgefaesse, während der Alkoholextrakt sie erweiterte,

3) Pituitrin verengerte die Ovarialgefaesse.

4) Kochsalzlösungs-sowie Alkoholextrakte der Schilddruse verengerten in konzentrierter Lösung die Ovarialgefässe des Rindes und erweiterten sie in verdünnter Lösung.

5) Hodenextrakt dilatiarte die Ovarialgefässe.

6) Kochsalzlösungsextrakt des Thymus führte in konzentrierter Lüsung zu Kontraktion oder vorübergehender Kontraktion und darauffolgender Dilalation der Ovarialgefässe, während er in verdünnter Lösung sie stets erweiterte. Der Alkoholextrakt des Thymus erweiterte die Ovarialgefaesse.

7) Der Kochsalzlösungsextrakt der Nebennierenrinde kontrahierte die Gefässe der Rinderovarien. Der Alkoholextrakt verursachte am Rinderovarien in starker Konzentration Gefässkontraktion, aber in schwacher Gefässdilatation. 
8) Insulin hatte keine Wirkung auf die Ovarialgefässe des Rindes. (Autoreferat.)

\section{Über die histologischen Besonder- heiten der Lebervenen. \\ I. Mitt. Über die Anordnung der glatten Muskeln in der Lebervenenwand und über das Vorkommen von Muskelwülsten an derselben beim Menschen und bei verschiedenen Tieren.}

Von

Dr. M. Takahashi

(Aus der I. Med. Klinik der Kaiserl. Universität zu Kyoto in Japan. Direktor: Prof. Dr. K. Tsuji.)

Der Verfasser studierte das Venensystem der Leber, besonders die Venae hepaticae, am Menschen und an verschiedenen 'Tieren und stellte dabei hinsichtlich der Muskelwülstebildung in der Lebervenenwand interessante Unterschiede zwischen dem Menschen und den untersuchten Tierarten fest, welche Unterschiede zur Erklärung der Sperrwirkung der Venae hepaticae von grosser Wichtigkeit sind.

Die wichtigsten Ergebnisse waren wie folgt.

1) Bei Karnivoren (Hund, Waschbärhund und Bär) finden sich die typischen Múskelwülste an dem peripheren Teil der Venae hapaticảe. Die Stärke der Muskelwülstebildung ist aber bei den Karnivoren je nach der Tierart sehr verschieden, und zwar sind die Muskelwülste am stärksten ausgeprägt beim Hund und Waschbärhund, schwach beim Bären und am schwächsten bei der Katze.

2) Bei Herbivoren, Nagetieren, Affen und Menschen fehlen die typischen Muskelwülste an der Lebervenenwand.

3) Der histologische Bau der grossen und mittelgrossen Venen 